\title{
DISCRIMINAÇÃO DE RAÇAS PRIMITIVAS DE PUPUNHA (Bactris gasipaes) NA AMAZÔNIA BRASILEIRA POR MEIO DE MARCADORES MOLECULARES (RAPDS) ${ }^{1}$
}

\author{
Nelcimar R. SOUSA ${ }^{2}$, Doriane P. RODRIGUES ${ }^{3}$, Charles R. CLEMENT ${ }^{4}$, \\ Eduardo O. NAGAO ${ }^{3}$, Spartaco ASTOLFI-FILHO 3
}

RESUMO - A pupunha (Bactris gasipaes Kunth, Palmae) foi domesticada por seu fruto pelos primeiros povos da Amazônia Ocidental, possuindo um complexo de raças primitivas (landraces) parcialmente caracterizado e mapeado morfologicamente. Ao longo dos Rios Amazonas e Solimões, no Brasil, foram propostas três raças primitivas [Pará (Rio Amazonas), Solimões (baixo e médio Rio Solimões), Putumayo (alto Rio Solimões)], com indicações de que a raça Solimões poderia ser artefato de análise morfométrica. Marcadores RAPDs foram usados para avaliar a hipótese de três raças. Extraiu-se DNA de 30 plantas de cada raça mantida no BAG de Pupunha em Manaus, AM, Brasil, Na amplificação por PCR, 8 primers geraram 80 marcadores, cujas similaridades de Jaccard foram estimadas para agrupamento das plantas com UPGMA. O dendrograma conteve 2 grandes grupos que juntaram-se a uma similaridade de 0,535: o grupo da raça Pará conteve 26 plantas dessa raça, 5 da Putumayo e 1 da Solimões; o grupo do Rio Solimões conteve 29 plantas da raça Solimões, 19 da Putumayo e 1 da Pará. A estrutura do segundo grupo sugere que existe apenas uma raça ao longo do Rio Solimões, pois as plantas amostradas são misturadas em sub-grupos sem ordem aparente. A análise genética não apoia a hipótese de três raças e sugere que a raça Putumayo estendese ao longo do Rio Solimões até Amazônia central. Será necessário juntar dados genéticos com morfológicos para avaliar esta nova hipótese com mais precisão.

Palavras-chave: variabilidade genética, biogeografia, ethnobotânica, análise genética

\section{Discrimination of Pejibaye (Bactris gasipaes) Landraces in Brazilian Amazonia using Mo- lecular Markers (RAPDs)}

ABSTRACT - The pejibaye (Bactris gasipaes Kunth, Palmae) was domesticated for it fruits by the first peoples of western Amazonia. Consequently it exhibits a landrace complex that has been partially characterized morphologically and mapped. Along the Amazonas and Solimões Rivers, in Brazil, three landraces have been proposed [Pará (Amazonas River), Solimões (lower and middle Solimões River), Putumayo (upper Solimões River)], with indications that the Solimões landrace could be an artifact of the morphometric analysis. RAPD markers were used to evaluate the three landrace hypothesis. DNA was extracted from 30 plants of each landrace maintained in the Pejibaye germplasm bank, Manaus, AM, Brazil. During PCR amplification, 8 primers generated 80 markers, Jaccard similarities were estimated, the plants were grouped with UPGMA. The dendrogram contained 2 large groups that joined at a similarity of 0.535; the group of the Para landrace contained 26 plants of this race, 5 of the Putumayo and 1 of the Solimões; the group of the Solimões River contained 29 plants of the Solimões race, 19 of the Putumayo and 1 of the Pará. The structure of the second group suggested that there is only one landrace along the Solimōes River, since the plants were mixed in sub-groups without apparent order. This marker-based genetic analysis did not support the three landrace hypothesis and suggests that the Putumayo landrace extends along the Solimões River to central Amazonia. Genetic and morphological data must now be used to evaluate this new hypothesis.

Key-words: genetic variability, biogeography, ethnobotany, genetic analysis

\footnotetext{
${ }^{1}$ Apoio do Programa Piloto para a Proteção das Florestas Tropicais do Brasil - PP/G7 - Projetos FINEP nº 0930/95 (Embrapa Amazônia Ocidental) e 0869/95 (INPA)

${ }^{2}$ Embrapa Amazônia Ocidental, Cx. Postal 319, 69011-970 Manaus, AM, Brasil

${ }^{3}$ Instituto de Ciências Biológicas, Universidade do Amazonas, 69077-000 Manaus, AM, Brasil

${ }^{4}$ Instituto Nacional de Pesquisas da Amazônia, Cx. Postal 478, 69011-970 Manaus, AM, Brasil
} 


\section{INTRODUÇÃO}

A pupunha (Bactris gasipaes Kunth, Palmae) é amplamente distribuida nos trópicos úmidos americanos (Mora Urpi et al., 1997), e possui ampla diversidade genética nas suas populações cultivadas devido a estas estarem em diferentes estágios de domesticação e em diferentes ambientes. Como conseqüência, possui um complexo de raças primitivas que foi parcialmente caracterizado morfologicamente e mapeado (Mora Urpi \& Clement, 1988). Estas raças foram criadas pelos primeiros povos da Amazônia ao longo de milhares de anos de domesticação partindo de bases genéticas diferentes ocorrendo em ambientes diferentes, com o resultado que cada raça possui caracteristicas morfológicas, químicas e produtivas próprias (Mora Urpi et al., 1997). Teoricamente, cada raça possui caracteristicas genéticas diferentes.

Ao longo dos Rios Amazonas e Solimões, no Brasil, foram propostas três raças primitivas de pupunha (Mora Urpi \& Clement, 1988): Pará (Rio Amazonas), Solimões (baixo e médio Rio Solimões) e Putumayo (alto Rio Solimões) (Fig. 1), com indicações que a raça Solimões poderia ser artefato da análise morfométrica (Clement, 1986). Portanto, é importante descobrir se as raças propostas com base em análises morfométricas são geneticamente confirmadas e se a análise genética poderá resolver as dúvidas observadas na análise morfométrica.
A caracterização morfométrica, com base numa lista minima de descritores para uso in situ e ex situ (Clement, 1986), permitiu a classificação das raças amazônicas de pupunha (Mora Urpí \& Clement, 1988). As raças foram identificadas como 'microcarpa', 'mesocarpa' e 'macrocarpa' com base no tamanho dos frutos e assumiu-se que o tamanho reflete o grau de domesticação da raça. A raça Pará (microcarpa), localizada ao longo do Rio Amazonas (Brasil), possui frutos pequenos, oleosos e fibrosos, e muitos frutos por cacho. A raça Solimões (mesocarpa), localizada ao longo do baixo e médio Rio Solimões (Brasil), possui frutos e cachos intermediários, e é uma das melhores para consumo direto porque sua textura é agradável e contém razoáveis niveis de caroteno e óleo, o que parece contribuir para seu sabor agradável. A raça Putumayo (macrocarpa), localizada ao longo do alto Rio Solimões (Brasil) e áreas adjacentes na Colômbia e Peru, possui frutos grandes, com muito amido e poucos frutos/cacho. Esta raça está começando a fornecer matéria-prima para o novo agronegócio de farinha para consumo humano, tanto na Amazônia ocidental como no Acre.

Com base na análise morfométrica usada para discriminar estas raças, Clement (1986) avaliou as relações fenéticas entre as raças no espaço discriminante. Das 8 raças amazônicas, apenas as três raças ao longo dos Rios Solimões e Amazonas não foram bem discriminadas, pois os volumes dos erros padrões ao redor de seus centróides se sobreporam. 


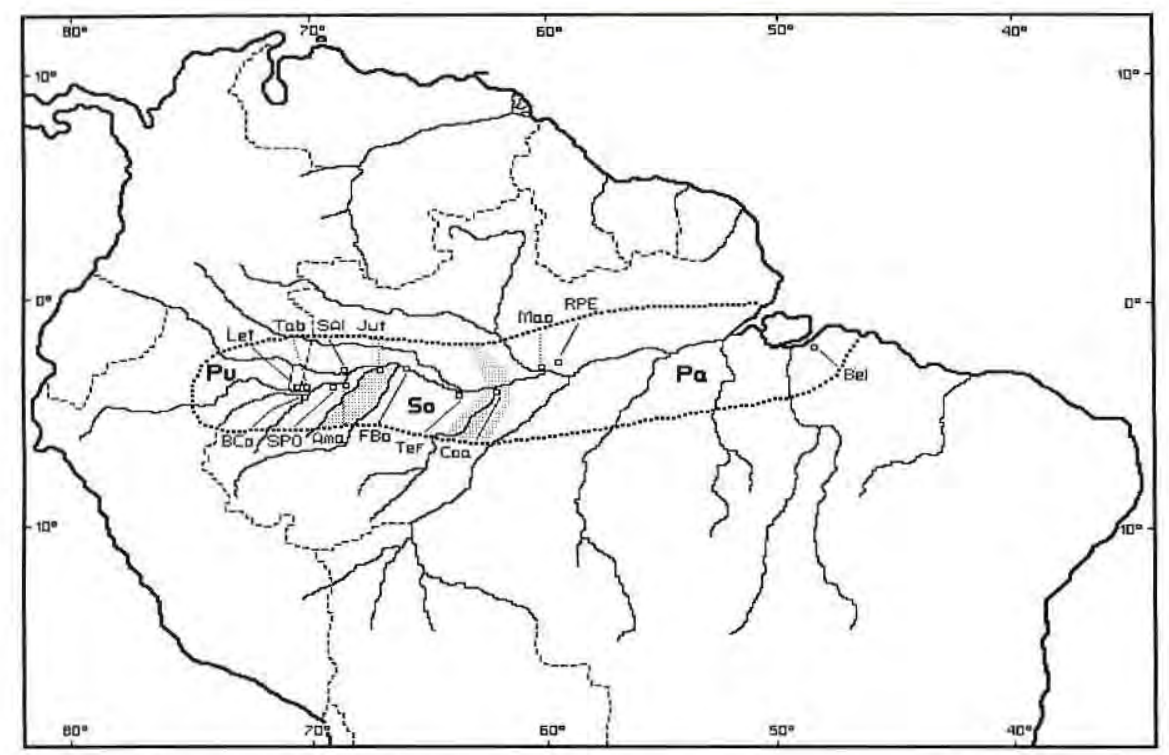

Figura 1. Distribuição geográfica das raças Pará, Solimões e Putumayo de pupunha (Bactris gasipaes) na Amazônia brasileira. As populações amostradas foram: Pará - Belém (Bel: 5 acessos; 12 plantas), Manaus (Mao: $4 \mathrm{ac} ; 7 \mathrm{pl}$ ), Rio Preto de Eva (RPE: $6 \mathrm{ac} ; 14$ pl); Solimões - Coari (Coa: 1 ac; 1 pl), Fonte Boa (FBo: 8 ac; 15 pl), Jutaí (Jut: 2 ac; 5 pl), Tefé (Tef: 4 ac; 9 pl); Putumayo - Amaturã (Ama: 2 ac; 5 pl), Benjamin Constant (BCo: 2 ac; 5 pl), Leticia, Colombia (Let: 2 ac; 4 pl), Santo Antonio do Içá (SAI: 1 ac; 2 pl), São Paulo de Olivença (SPO: 1 ac; $2 \mathrm{pl}$ ), Tabatinga (Tab: $6 \mathrm{ac} ; 12 \mathrm{pl}$ ).

Esta sobreposição sugeriu que existe muita introgressão entre estas raças (que é uma suposição lógica devido a sua distribuição linear ao longo destes rios) ou que a raça Solimões é um artefato da análise morfomética (já que a análise discriminante testou uma hipótese de existência do complexo de raças na Amazônia e não apenas ao longo do Solimões/Amazonas). A segunda possivel dúvida merece atenção especifica porque a hipótese testada com a análise discriminante foi baseada nas impressões visuais de um grupo de pessoas (Mora Urpi \& Clement, 1988), em lugar de estar baseada numa análise estatística exploratória. Estas dúvidas sobre a raça Solimões podem ser resolvidas por meio de análises moleculares.

Atualmente, o uso de marcadores moleculares é uma ferramenta complementar para caracterização de germoplasma (Ferreira \& Grattapaglia, 1996) e, conseqüentemente, para identificação de populações e raças primitivas. Os marcadores moleculares possuem a vantagem de não sofrer efeitos ambientais, tornando-os confiáveis em qualquer ambiente. A caracterização molecular não substitui a caracterização morfológica, mas ajuda a entender melhor a relação genética entre raças e populações. $\mathrm{O}$ objetivo deste estudo é de avaliar a hipótese de três raças de pupunha (Pará, Solimões e 
Putumayo) com base na caracterização molecular por RAPDs.

\section{MATERIAL E MÉTODOS}

Na Amazônia brasileira, o Instituto Nacional de Pesquisas da Amazônia mantém o Banco Ativo de Germoplasma de Pupunha (BR 174, $\mathrm{km} \mathrm{38,} \mathrm{Manaus,} \mathrm{AM,} \mathrm{Brasil),} \mathrm{em}$ colaboração com a Embrapa Recursos Genéticos e Embrapa Amazônia Ocidental. O BAG contém 450 acessos coletados de populações cultivadas e 5 de silvestres. Utilizouse 91 plantas de três raças, sendo 30 de cada uma das raças Pará $(+1$ planta desta raça, que foi usada em todos os géis), Solimões e Putumayo. As plantas foram selecionadas para representar a distribuição brasileira da raça Putumayo, a maioria da distribuição da raça Solimões (a parte oriental é mal representada no BAG-Pupunha e não foi incluida), e a parte ocidental e oriental da raça Pará (a parte central é mal representada no BAG-Pupunha, e não foi incluida). A Figura 1 apresenta as populações amostradas e o número de acessos e plantas em cada.

Extraiu-se o DNA com o DNAsy Plant Mini-kit da Quiagen, utilizando-se $100 \mathrm{mg}$ do meristema apical de um estipe lateral, como praticado por Clement et al. (1997) na extração de enzimas, obtendo-se em média( \pm desvio padrão) $72 \pm 30$ ng de DNA/ml (minimo 16; máximo $140 \mathrm{ng} / \mathrm{ml}$ ). Os RAPDs foram obtidos conforme Williams et al. (1990): as reações de amplificação para volume final de $30: 1$ continham $3 \mathrm{ml}$ de DNA genômico $(5 \mathrm{ng} / \mathrm{ml}), 3 \mathrm{ml}$ de dNTP (2,5 mM), 4,2 $\mathrm{ml}$ de $\mathrm{MgCl}_{2}$ (25 $\mathrm{mM}), 7 \mathrm{ml}$ do "primer" (10 ng/ml), 1,5 U de enzima "Taq polimerase" (CENBIOT/RS) e $3 \mathrm{ml}$ de Tampão $10 \mathrm{X}$ (Tris-HCl $200 \mathrm{mM} \mathrm{pH}=8,6$; $\mathrm{KCl} 500 \mathrm{mM}$ ). As amostras foram amplificadas em termociclador (Perkin Elmer 9600) programado para 1 etapa de 2 min a $94^{\circ} \mathrm{C}, 40$ ciclos de $1 \mathrm{~min}$ a $92^{\circ} \mathrm{C}, 1 \mathrm{~min}$ a $36^{\circ} \mathrm{C}$ e 2 min a $72^{\circ} \mathrm{C}$, mais 1 etapa de $3 \mathrm{~min}$ a $72^{\circ} \mathrm{C}$. Os primers utilizados foram da Operon Technologies (Tab. 1). Os RAPDs foram separados em gel de agarose $(1,5 \%)$, visualizados por fluorescência com brometo de etidio e fotografados para posterior interpretação.

As duas primeiras e últimas fileiras (plantas) em cada gel foram descartadas em função da baixa qualidade fotográfica nas bordas, sendo considerada na análise 27 plantas da raça Pará, 30 da Solimões e 24 da Putumayo. Bandas foram codificadas como presente ou ausente. As similaridades de Jaccard foram estimadas da matriz binária; a matriz de similaridades foi usada para gerar um dendrograma com base em UPGMA (Rolf, 1990).

\section{RESULTADOS E DISCUSSÃO}

$\mathrm{Na}$ amplificação por PCR, os 8 primers geraram 80 marcadores que poderiam ser usados com 
razoável confiança (56 foram descartados por pouca resolução). Destes 80 marcadores, 71 foram polimórficos no conjunto das plantas, mas cada raça apresentou um número diferente e menor que este (Tab. 1).

O dendrograma conteve 2 grandes grupos que se juntaram a uma similaridade de 0,535 (Fig. 2). O grupo da raça Pará conteve 26 plantas dessa raça, 5 da Putumayo e 1 da Solimões. O grupo do Rio Solimões conteve 29 plantas da raça Solimões, $19 \mathrm{da}$ Putumayo e 1 da Pará.

Detectou-se quatro possiveis problemas com esta análise: (1) a maior similaridade entre indíviduos dentro dos grupos foi de 0,85 , na raça Pará, que é mais distante do que esperado a priori; se esperava que individuos de um mesmo acesso (oriundos da mesma matriz) teriam similaridades $>0,90 ;$ (2) a similaridade entre grupos foi muito pequena $(0,535)$, que é uma distância esperada entre espécies e não entre raças dentro de uma espécie; (3) a presença de plantas estranhas em cada grupo, ou seja, que estavam fora do grupo esperado, o que poderia ser erro de plantio, de coleta da amostra ou de manipulação da amostra no laboratório; cada planta estranha ao seu grupo precisará ser reanalisada futuramente para determinar se foi erro ou realmente é membro de outro grupo; (4) individuos do mesmo acesso encontrados em dois ou mais subgrupos, quando se esperava que estes individuos formariam os subgrupos; esta situação foi observada em Elaeis oleifera também, embora em menor frequência (E. Barcelos, Embrapa, com. pess.).

O grupo da raça Pará apresentou

Tabela 1. Número de marcadores (RAPDs) úteis obtidos de cada primer (Operon) usado nas três raças de pupunha (Bactris gasipaes) e número de marcadores polimórficos em cada raça.

\begin{tabular}{cccccc}
\hline & $N^{\circ}$ & \multicolumn{5}{c}{$N^{\circ}$ Polimórficos } \\
\cline { 2 - 6 } Primer & Marcadores & Total & Pará & Solimões & Putumayo \\
\hline OPA-01 & 5 & 5 & 5 & 3 & 5 \\
OPA-04 & 10 & 8 & 7 & 8 & 8 \\
OPA-05 & 15 & 12 & 11 & 12 & 12 \\
OPA-08 & 13 & 13 & 11 & 13 & 12 \\
OPA-09 & 11 & 10 & 9 & 9 & 9 \\
OPA-18 & 12 & 12 & 11 & 9 & 10 \\
OPA-20 & 9 & 9 & 9 & 9 & 8 \\
OPAV-15 & 5 & 2 & 2 & 1 & 2 \\
Total & 80 & 71 & 65 & 64 & 66 \\
\hline
\end{tabular}




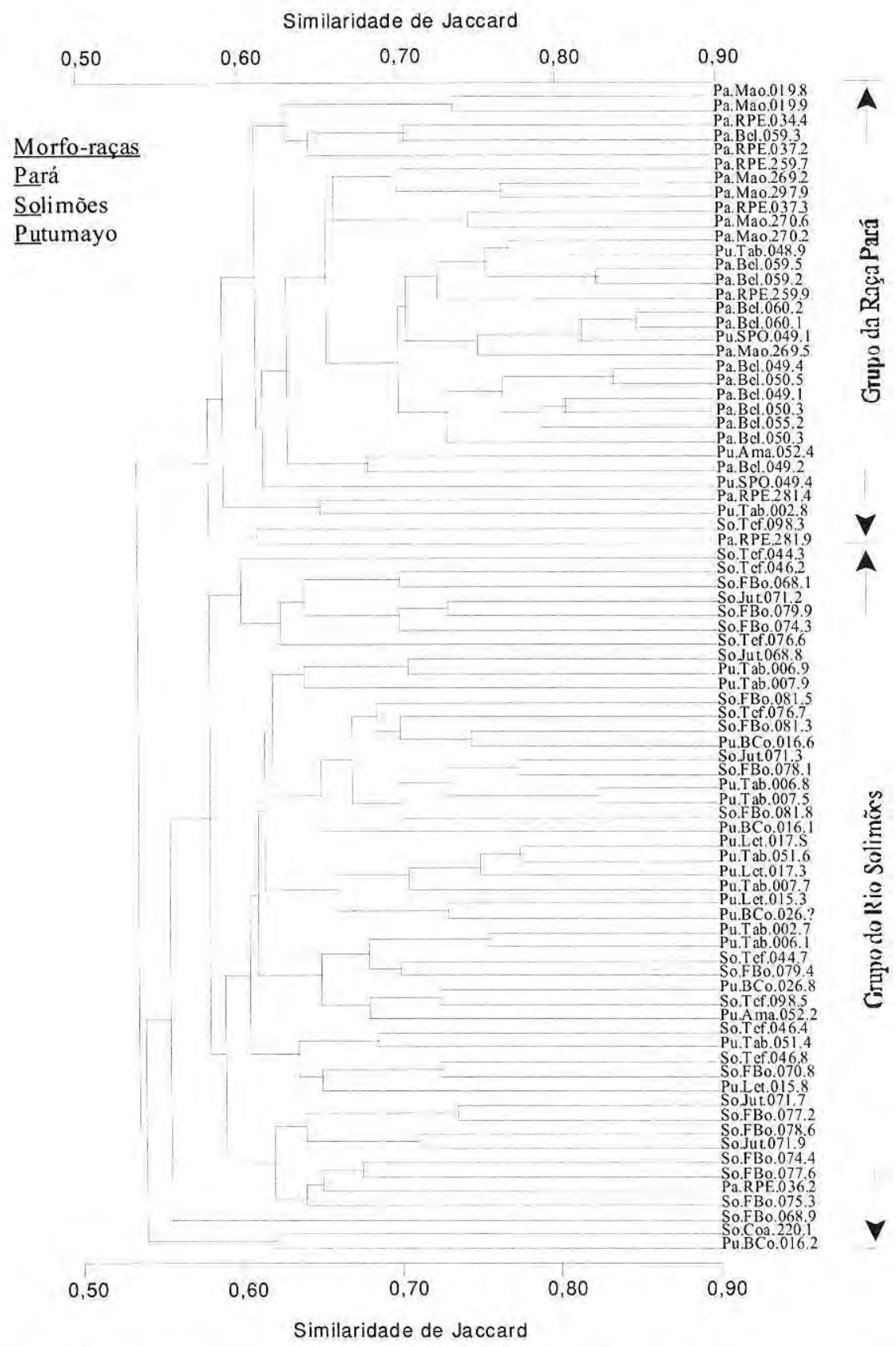

Figura 2. Dendrograma das relações entre plantas de pupunha (Bactris gasipaes) com base na similaridade de Jaccard estimado da matriz binária de 80 marcadores RAPDs. Chave: rr.ppp.nnn.n, onde rr são as primeiras letras do nome da raça, ppp são as abreviações das populações descritas na Figura 1, e nnn.n são a numeração do acesso e da planta no BAGPupunha, INPA, Manaus, AM. 
6 subgrupos e um individuo. Os dois primeiros subgrupos (do topo da Fig. 2) representaram Amazônia central, o terceiro representou Amazônia oriental, com duas plantas estranhas ao grupo, e os outros 3 contiveram pares de plantas com uma própria do grupo e uma estranha ao grupo. O grande número de plantas estranhas neste grupo $(19 \%)$ pode ser devido aos possíveis erros apontados acima, ou ao fato que já houve muito introdução de germoplasma do alto Rio Solimões (raça Putumayo, especialmente) em Belém e Manaus (Mora Urpí \& Clement, 1988), o que poderia influenciar as similaridades.

O grupo do Rio Solimões apresentou 8 subgrupos e um individuo. O primeiro subgrupo representou a raça Solimões, os próximos três subgrupos misturaram as raças Solimões e Putumayo, o quinto representou a raça Putumayo, os próximos dois misturaram as raças Solimões e Putumayo, o penúltimo representou a raça Solimões (com uma estranha), e o último subgrupo juntou uma planta do extremo oriental da raça Solimões com uma da raça Putumayo. A ausência de uma estrutura que diferencie a raça Solimões da raça Putumayo sugere que existe apenas uma raça ao longo do Rio Solimões.

Conclui-se que a análise genética não apoia a hipótese de três raças. Em lugar disto, a análise sugere que a raça Putumayo estende-se ao longo do Rio Solimões até Amazônia Central. A raça Pará é apoiada por esta análise, embora ainda seja necessário determinar seu limite ocidental. Desta forma, será necessário juntar dados genéticos com morfológicos para avaliar esta nova hipótese com mais precisão.

\section{Bibliografia citada}

Clement, C.R. 1986. Descriptores minimos para el pejibaye (Bactris gasipaes H.B.K.) y sus implicaciones filogenéticas. Tese de mestrado, Escuela de Biologia, Universidade de Costa Rica, San José, Costa Rica. 216p.

Clement, C.R.; Aradhya, M.K.; Manshardt, R.M. 1997. Allozyme variation in spineless pejibaye (Bactris gasipaes Palmae). Economic Botany, 51(2):149-157.

Ferreira, M.E.; Grattapaglia, D. 1996. Introdução ao uso de marcadores moleculares em análise genética. Embrapa-CENARGEN, Brasilia. 220p.

Mora Urpi, J.; Clement, C.R. 1988. Races and populations of peach palm found in the Amazon basin. In: Clement, C.R.; Coradin, L. (Eds.). Final report (revised): peach palm (Bactris gasipaes H.B.K.) germplasm bank. U.S. A.I.D. project report. Instituto Nacional de Pesquisas da Amazonia/Centro Nacional de Recursos Geneticos, Manaus, Amazonas. pp. 78-94.

Mora Urpi, J.; Weber, J.C.; Clement, C.R. 1997. Peach palm. Bactris gasipaes Kunth. Promoting the conservation and use of underutilized and neglected crops. 20. Institute of Plant Genetics and Crop Plant Research - IPK, Gatersleben/International Plant Genetic Resources Institute - IPGRI, Rome. 83 p.

Rolf, F.J. 1990. NTSYS-pc - Numerical taxonomy and multivariate analysis system. ver: 1.6. Exeter Software, Setauket, NY.

Williams, J.G.K.; Kubelik, A.R.; Livak, K.J.; Rafalski, J.A.; Tingey, S.V. 1990. DNA polymorphisms amplified by arbitrary primers are useful genetic markers. Nucleic Acid Research, 18:6531-6535. 